\title{
Population biology of shrimp Artemesia longinaris (Crustacea: Decapoda: Penaeidae) from the southern coast of Brazil
}

\author{
ROGÉRIO CAETANO DA COSTA ${ }^{1}$, JOAQUIM OLINTO BRANCO ${ }^{2}$, IRECÊ FARINA MACHADO ${ }^{3}$, \\ BRUNO RIBEIRO CAMPOS ${ }^{4}$ AND MARCELO GENTIL AVILA ${ }^{2}$ \\ ${ }^{1}$ LABCAM, Departamento Ciências Biológicas-Faculdade de Ciências-UNESP, Bauru, SP, Brazil, Avenida Eng. Edmundo Carrijo \\ Coube, s/n-Vargem Limpa, 17033-36o, Brazil, ${ }^{2}$ Centro de Ensino em Ciências Tecnológicas da Terra e do Mar, UNIVALI. Caixa \\ Postal 360, 88301-970, Itajaí, Santa Catarina, Brazil, ${ }^{3}$ Laboratório de Crustáceos Decapodos, ${ }^{4}$ Laboratório de Aqüicultura, Instituto \\ de Oceanografia-Universidade Federal do Rio Grande-FURG, Km 8 Rio Grande (RS), 96201-90o, Brazil
}

\begin{abstract}
Size at morphological sexual maturity, sex-ratio, and the seasonal variation in abundance of the shrimp Artemesia longinaris Bate, 1888 were assessed off Pinheira Beach, Palhoça, Santa Catarina southern Brazil. Shrimp were collected monthly from November 2003 through to October 2004, in two areas that are customarily used by local traditional fishermen $\left(27^{\circ} 52^{\prime}-\right.$ $27^{\circ} 51^{\prime} S$ and $48^{\circ} 33^{\prime}-48^{\circ} 29^{\prime} W$ ). Of the total of 1099 specimens measured, $23.93 \%$ were males and $76.07 \%$ females. Mean size at first maturity $\left(L_{50}\right)$ was estimated as $56.38 \mathrm{~mm}$ total length (TL) for males, and $70.34 \mathrm{~mm}$ TL for females. Females were significantly larger than males. Abundance of juveniles varied seasonally. A high predominance of juveniles in the areas sampled occurred in winter for both sexes, and in spring for females. In the summer and autumn, we observed a decrease in juveniles in both areas, mainly, area II. We suggest that the differential migration pattern of sexes during the reproductive cycle was the principal reason for the larger catch of females. The classical paradigm of continuous reproduction at lower latitude, with increased seasonality of the breeding period at higher latitudes, seems to apply to this species.
\end{abstract}

Keywords: maturity, recruitment, distribution, sex ratio, shrimp fishery, Brazil

Submitted 30 April 2009; accepted 10 September 2009; first published online 19 January 2010

\section{INTRDDUCTION}

Shrimps of the suborder Dendrobranchiata are among the most important marine fishery resources in the world: the group includes several commercially important species constituting an important food resource for humans (Costa et al., 2007). Among this suborder, the family Penaeidae includes some of the most commercially important shellfish inhabiting the south-eastern and southern Brazilian coast, which have significant historical, social and cultural importance (D'Incao et al., 2002; Branco, 2005).

The shrimp fisheries of southern Brazil target the most profitable species, such as the pink shrimps Farfantepenaeus brasiliensis (Latreille, 1817) and F. paulensis (Pérez-Farfante, 1967) and the seabob shrimp Xiphopenaeus kroyeri (Heller, 1862). The increase in the fishing fleet and the decrease in landings of the customarily exploited species have contributed to an expanding interest in the shrimp Artemesia longinaris Bate, 1888, locally known as the barba-ruça (Costa et al., 2005; Castilho et al., 2008a).

The geographical distribution of $A$. longinaris is restricted to the western Atlantic, from Brazil (Rio de Janeiro to Rio Grande do Sul), through Uruguay to the Province of

Corresponding author:

R.C. da Costa

Email: rccosta@fc.unesp.br
Chubut, Argentina. This shrimp is found from shallow water to $30 \mathrm{~m}$ (Boschi, 1997; Costa et al., 2003), and lives exclusively in the marine environment throughout its life cycle (Rodriguez et al., 2002; Branco, 2005; Costa et al., 2005).

Of the available information on $A$. longinaris, most accounts are drawn from populations in Argentinean waters (Boschi \& Mistakidis, 1966; Boschi, 1969, 1997; Boschi \& Scelzo, 1977; Gavio \& Boschi, 2004). Some information about the biology of the species was obtained from the southern Brazilian coast, specifically in the States of São Paulo and Rio de Janeiro, including reports on population and breeding dynamics (Castilho et al., 2007a, b; Semensato \& Di Beneditto, 2008) and ecological distribution (Costa et al., 2005). These authors found that age, maturity and carapace length of this species increase at higher latitudes. Additionally, Castilho et al. (2007b) observed that reproduction and juvenile recruitment are continuous for individuals of A. longinaris caught on the São Paulo coast (tropical regions $=23^{\circ} \mathrm{S}$ ), but these events are seasonal in samples obtained in the Mar del Plata (cool-temperate $=37^{\circ} \mathrm{S}$ ).

One of the main objectives in the study of the reproductive ecology of benthic invertebrates is to assess latitudinal trends in the timing of reproductive activity and recruitment of juveniles (Bauer, 1992; Costa \& Fransozo, 2004). The State of Santa Catarina is located between $25^{\circ} 5^{\prime} 741^{\prime \prime}-29^{\circ} 23^{\prime} 55^{\prime \prime} \mathrm{S}$ and $48^{\circ} 19^{\prime} 37^{\prime \prime}-53^{\circ} 50^{\prime} 00^{\prime \prime} \mathrm{W}$, and has a subtropical climate. In this region, there are only a few accounts of the reproduction of dendrobranchiate shrimps. Almost all the available 
information deals with populations of Farfantepenaeus spp. (Branco \& Verani, 1998a, b) and Xiphopenaeus kroyeri (Branco et al., 1999; Branco \& Fracasso, 2004; Branco, 2005). Information about the biology of $A$. longinaris is nonexistent.

The purpose of the present study was to determine the size at morphological maturity and the sex-ratio of A. longinaris, and to assess the seasonal variation in recruitment of juveniles off Pinheira Beach, Palhoça, Santa Catarina, in subtropical Brazil. Additionally, we compared our findings with those obtained for the same species in tropical and temperate regions. The sex-ratio and temporal distribution of the local population of this species were also evaluated.

\section{MATERIALS AND METHDDS}

Shrimp were collected monthly from November 2003 through to October 2004 off Pinheira Beach, Palhoça, State of Santa Catarina, Brazil. The samples were collected in two areas where traditional fishermen customarily work $\left(27^{\circ} 52^{\prime}-\right.$ $27^{\circ} 51^{\prime} \mathrm{S}$ and $\left.48^{\circ} 33^{\prime}-48^{\circ} 29^{\prime} \mathrm{W}\right)$. One trawl was carried out in each area, at depths of $19 \mathrm{~m}$ (area I) and $30 \mathrm{~m}$ (area II) A boat ( $9 \mathrm{~m}$ long by $3 \mathrm{~m}$ wide) equipped with double-rigged nets (mesh $3.0 \mathrm{~cm}$ and $2.0 \mathrm{~cm}$ in the cod end) was used for trawling, which lasted for 1 hour in each area. Bottom salinity and temperature were monitored in each area. Detailed descriptions of the sampling methods and analysis of environmental factors for the period are available elsewhere (Branco, 2005).

When a large number of individuals were caught in a trawl, a subsample of $500 \mathrm{~g}$ total biomass was separated randomly for examination of the sex and length of each individual. All the individuals sorted were sexed and measured (to the nearest $0.1 \mathrm{~mm}$ ). When the catch did not exceed $500 \mathrm{~g}$, all the shrimp were measured. The parameters used for the biometry of $A$. longinaris were: total length, including rostrum (TL, $\mathrm{mm}$ ) and carapace length, excluding the rostrum $(\mathrm{CL}, \mathrm{mm})$. The reproductive status of males was assessed by examining the shape of the petasma, which is fused in adult individuals. The adult females were determined by macroscopic observation of the degree of ovarian development (colour and volume occupied by the gonads). Ovaries categorized as immature ranged from thin, transparent strands to thicker ones. Mature ovaries were much larger and thicker, and varied from yellow to light orange or light green, and green to olive-green (Dumont \& D'Incao, 2004). Size-frequency distributions were constructed separately to estimate the seasonality for males and females, using $10-\mathrm{mm}$ TL size-intervals.

From the total length, we obtained the maximum and minimum size-ranges for each sex, and plotted the relative frequencies (\%) of adults in each size-class. The log function $y=$ $1 / 1+e^{r\left(T L-T L_{50}\right)}$ was fitted to the data, where $T L_{50}$ corresponds to the size at which $50 \%$ of the individuals are considered adults, and $r$ stands for the slope of the curve. The curves were fitted by the least-squares method (Vazzoler, 1996), which requires a size-range overlap of adults and young of at least two size-classes. The shrimp were therefore classed in 10-mm size-intervals.

Recruitment was defined as the percentage of juveniles of the total number of individuals of males and females in each month and season of the year. Size-classes of juveniles were defined separately for males and females. The sex-ratio in each month was compared using the $\chi^{2}$-test $(P<0.05$ and df $\mathrm{N}-1$ ). The mean sizes (TL) of males and females were compared by Student's $t$-test (Zar, 1984).

In order to assess the effect of the traditional fishery on juvenile and adult shrimp, we used as a basis, the size at first gonadal maturation and the frequency distribution by size-class of males and females (Branco et al., 1999).

\section{RESULTS}

Monthly mean bottom seawater temperature and salinity are shown in Figure 1. Mean bottom water temperature sampled between November 2003 and October 2004 varied between 15.9 and $26.9^{\circ} \mathrm{C}\left(21.1 \pm 3.6^{\circ} \mathrm{C}\right)$ in the bay and the

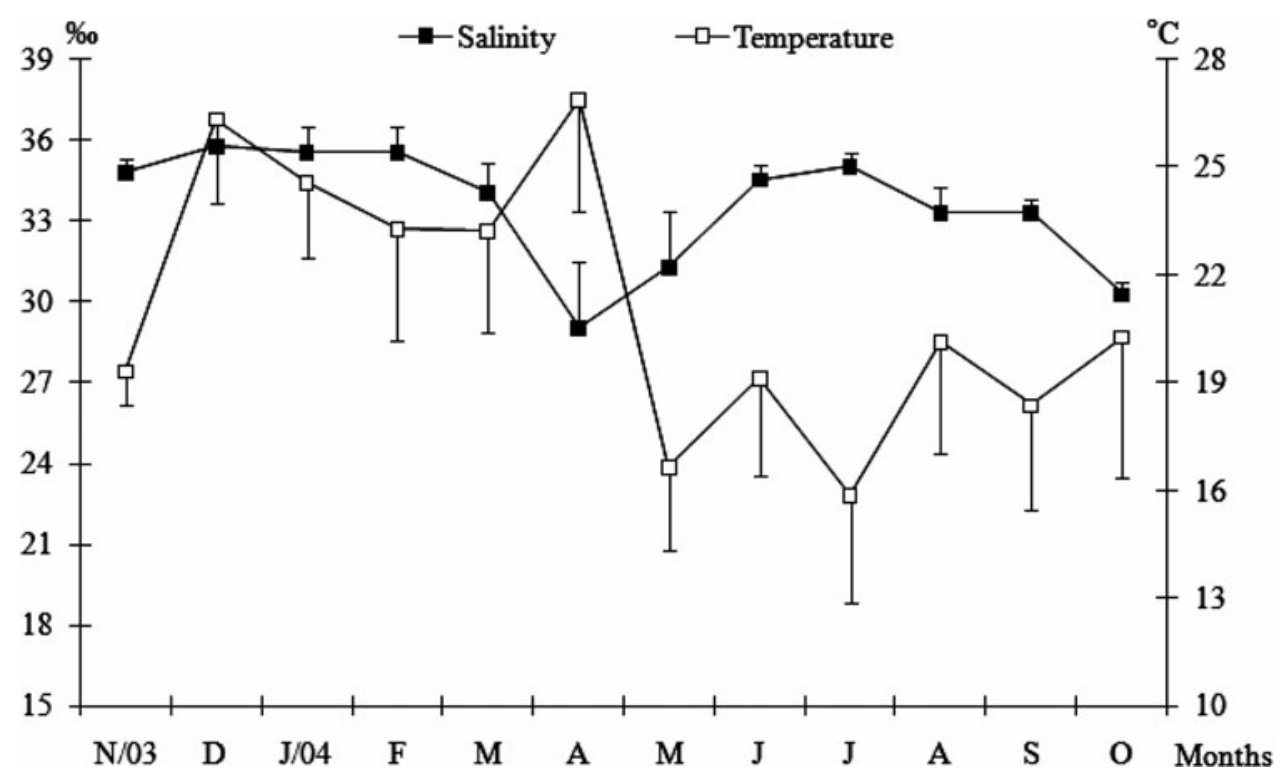

Fig. 1. Mean values of seawater bottom temperature and salinity recorded monthly from November 2003 through to October 2004 in the Palhoça region, Santa Catarina. 
water salinity varied between 29 and $35.8 \%$ o (33.5\% \pm 2.2$)$, respectively

Of the total of 1099 specimens analysed, $23.93 \%$ were males and $76.07 \%$ females. The sex-ratio, calculated for all the individuals caught, was significantly different from 1:1 $(P<0.05$, $\chi^{2}$-test). Monthly sex-ratios were significantly biased towards females in November and December 2003, and March, May, and July through to October 2004. In the other months, the sex proportion was similar (Figure 2).

The relationship of $\mathrm{CL}$ and TL was represented by the expressions $\mathrm{CL}=0.1645 \mathrm{TL}(\mathrm{r}=0.80)$ for males; and $\mathrm{CL}=$ $0.1904 \mathrm{TL}=(\mathrm{r}=0.88)$ for females. The $\mathrm{TL}_{50}$ was estimated as $56.38 \mathrm{~mm}(\mathrm{CL}=9.3 \mathrm{~mm})$ for males, and $70.34 \mathrm{~mm}$ $(\mathrm{CL}=13.4 \mathrm{~mm})$ for females (Figure 3 ).

Seasonal and spatial size - frequency distributions for males and females for A. longinaris are shown in Figure 4. In both localities, females reached a larger size than males, and were most abundant in the size-classes from 60 to $120 \mathrm{~mm}$ TL ( $P$ $<0.05)$. No male was collected between the lengths of 110 and $120 \mathrm{~mm}$. Overall, the mean size for males was $56.5 \pm 11.9 \mathrm{~mm}$ $\mathrm{TL}$, ranging from $29(\mathrm{CL}=4.8 \mathrm{~mm})$ to $92 \mathrm{~mm} \mathrm{TL}(\mathrm{CL}=$ $15.3 \mathrm{~mm}$ ); the mean size for females was $67.2 \pm 16.4 \mathrm{TL}$, ranging from $27(\mathrm{CL}=5.1 \mathrm{~mm})$ to $112 \mathrm{~mm} \mathrm{TL}(\mathrm{CL}=$ $21.3 \mathrm{~mm})$. Females were significantly larger than males $(t=$ 9.7, $P<0.001$ ). The mean and minimum and maximum TL in each area for both sexes are listed in Table 1.

Juveniles of $A$. longinaris were found in all months (Table 2). The highest percentage of juveniles in relation to adults occurred in November 2003, March, April and July to September 2004. In general, the traditional fishery effort at Pinheira Beach is mainly concentrated on the stocks of juveniles (Figure 4; Table 2), that is, $75.7 \%$ of the males, and $63.4 \%$ of the females caught were juveniles. A high predominance of juveniles in the areas sampled occurred in winter (July to September) for both sexes, and in spring for the females. In the summer and autumn, we observed a decrease in juveniles abundance in both areas, mainly, area II (Figure 4).

\section{DISCUSSION}

Sex-ratio was strongly skewed towards females in this population of A. longinaris. Monthly, and in most size-classes,

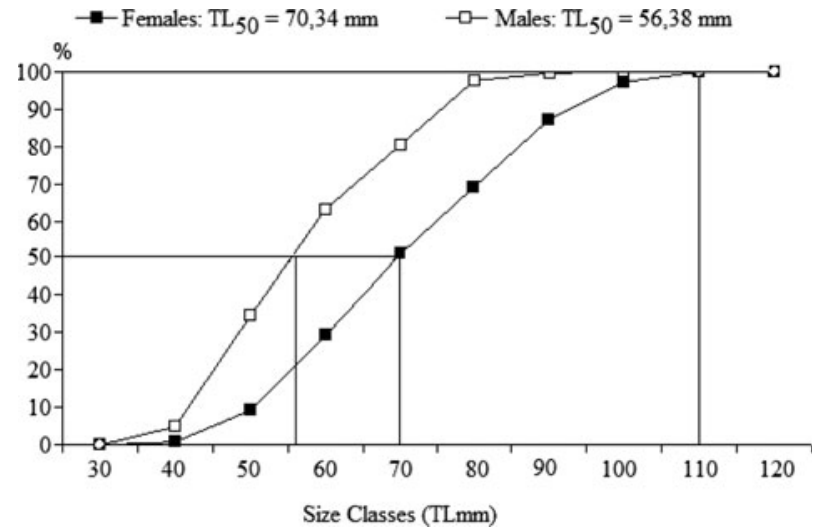

Fig. 3. Sexual maturity based on the $\mathrm{TL}_{50} \%$ (total length) of females and males of Artemesia longinaris collected off Pinheira Beach, Palhoça, Santa Catarina, from November 2003 through to October 2004.

females were always more abundant than males. Several hypotheses might be proposed to explain this observation. For instance, Cha et al. (2002) attributed the annual sex-ratio in favour of Penaeus chinensis Osbeck, 1765 females to greater mesh-size selectivity. Additionally, we can suggest that the sex-ratio in favour of A. longinaris females may be related to greater vulnerability of females to fishing because of their size. However, in most of the size-classes that included juvenile females, the sex-ratio was still strongly skewed towards females. This suggests that sampling bias cannot account for the observed sex-ratio.

Kevrekidis \& Thessalou-Legaki (2006) postulated an operating factor 'such as higher female catchability for Melicertus kerathurus (Forskål, 1775), due to longer foraging in order to meet increased food requirements during ovary maturation.' Cha et al. (2002) suggested that the predominance of adult females in $P$. chinensis might be related to a possible breeding period that caused higher natural mortality of males because of mating. Castilho et al. (2008b) proposed for Sicyonia dorsalis Kingsley, 1878, that the female-biased sexratio might be favoured in populations in which females are polygynous. Here we suggest another hypothesis for A. longinaris: differential migration between the sexes during the reproductive cycle. Copulation would occur in deep water,

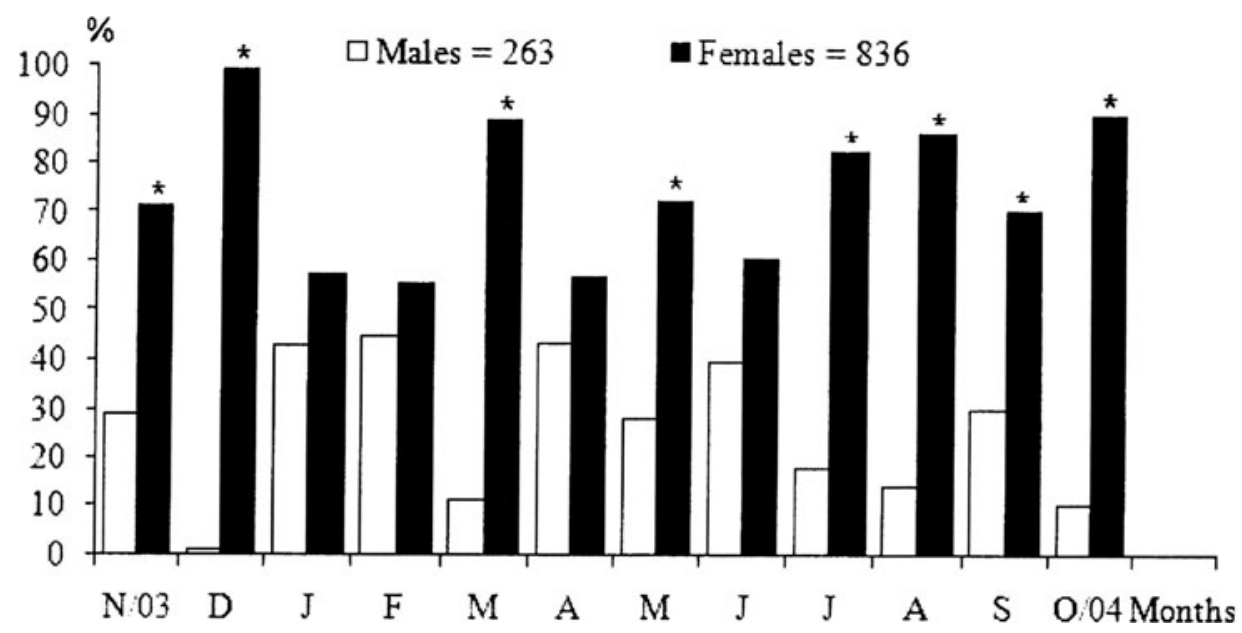

Fig. 2. Proportions (\%) of males and females of Artemesia longinaris collected off Pinheira Beach, Palhoça, Santa Catarina, from November 2003 through to October 2004. *, significant difference, $\chi^{2}(P<0.05)$. 

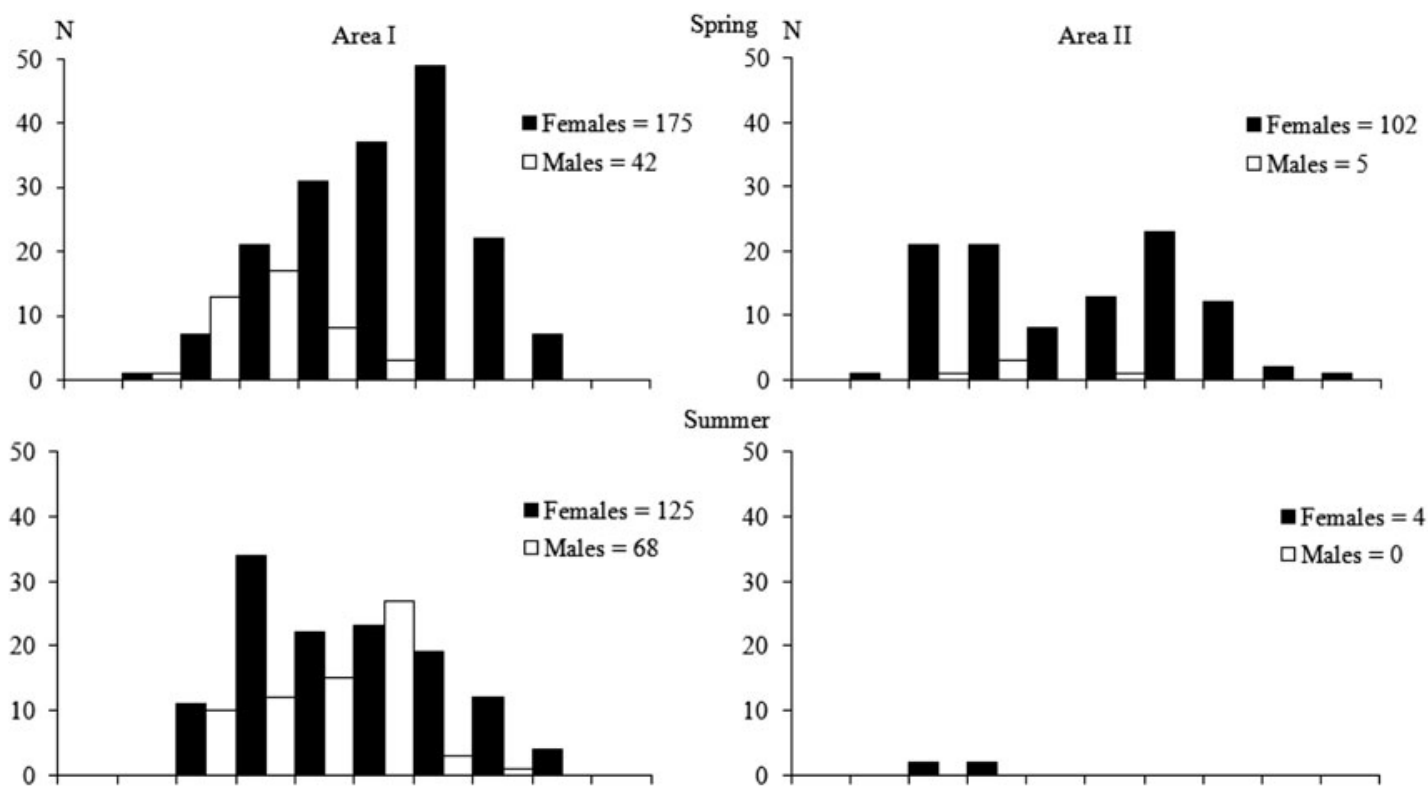

Summer
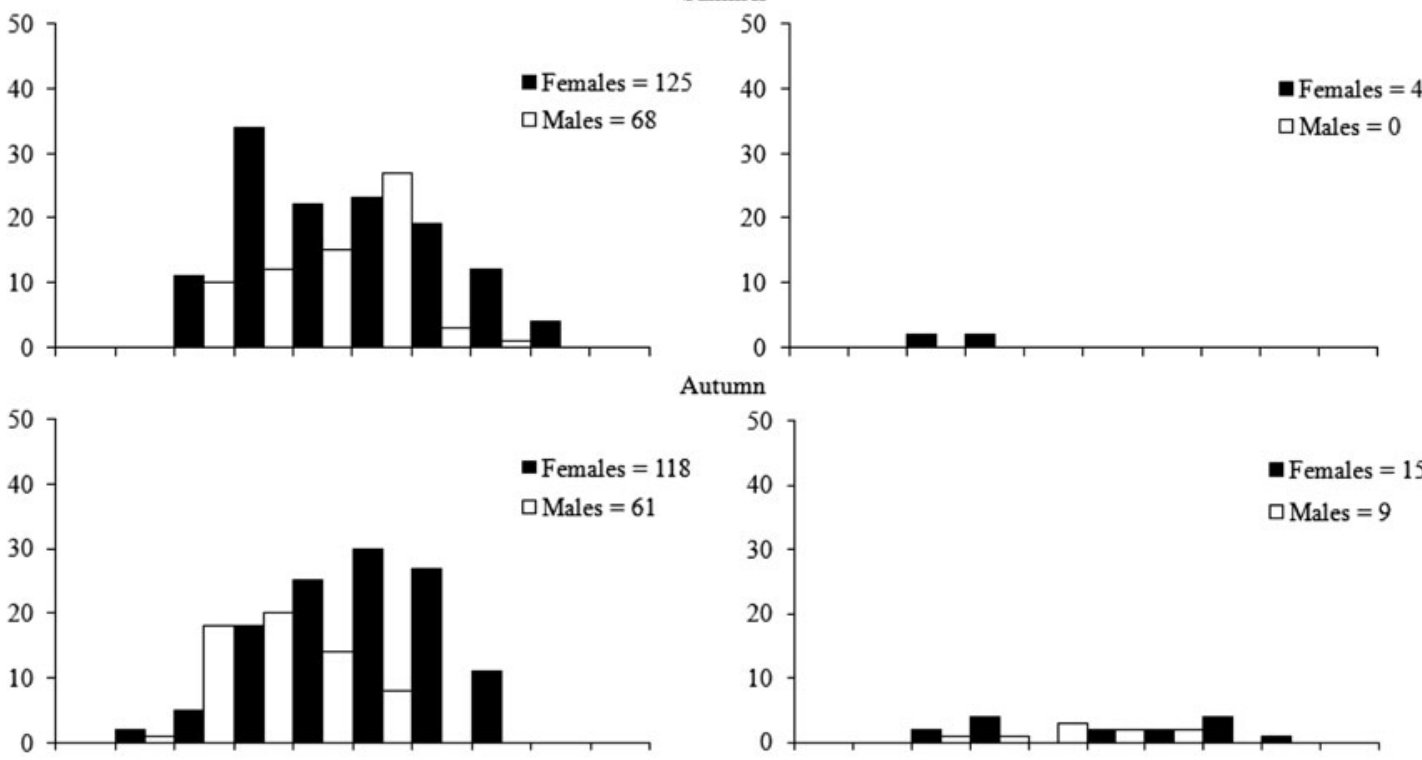

Autumn
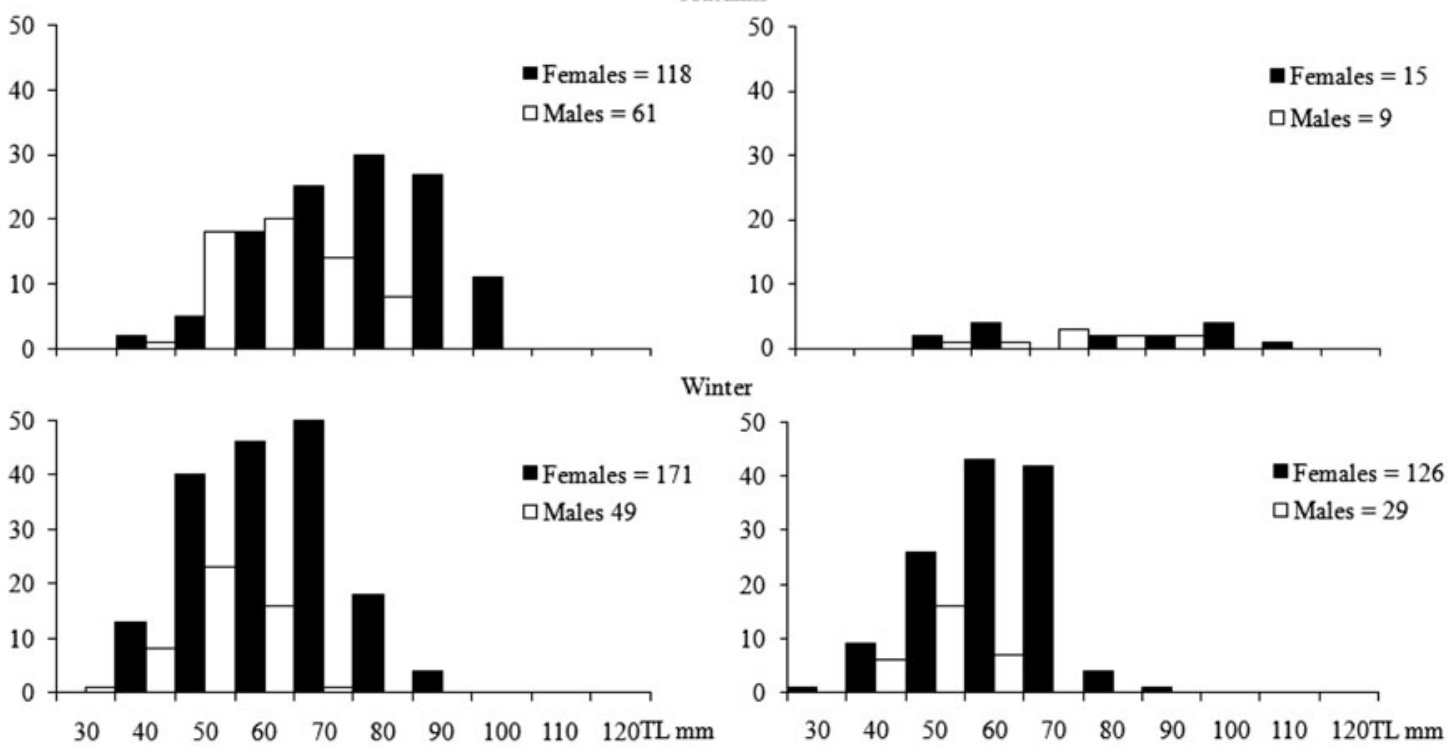

Fig. 4. Seasonal distribution of number of shrimps in each size-class (TL, mm) of males and females of Artemesia longinaris collected off Pinheira Beach, Palhoça, Santa Catarina, from November 2003 through to October 2004.

Table 1. Number $(\mathrm{N})$, total length $(\mathrm{mm})$ and carapace length $(\mathrm{mm})$ of Artemesia longinaris in the two collecting areas, with their respective ranges, means (M) and standard errors (SE), off Pinheira Beach, Palhoça, Santa Catarina, from November 2003 through to October 2004.

\begin{tabular}{|c|c|c|c|c|c|c|c|c|}
\hline & & \multicolumn{4}{|c|}{ Total length (mm) } & \multicolumn{3}{|c|}{ Carapace length (mm) } \\
\hline & & $\mathbf{N}$ & $<$ & $>$ & $M \pm S E$ & $<$ & $>$ & $\mathrm{M} \pm \mathrm{SE}$ \\
\hline \multirow[t]{2}{*}{ Males } & Area I & 220 & 29.0 & 92.0 & $57.23 \pm 0.80$ & 6.0 & 17.0 & $10.40 \pm 0.15$ \\
\hline & Area II & 43 & 35.0 & 87.0 & $52.37 \pm 1.82$ & 7.0 & 16.0 & $10.06 \pm 0.32$ \\
\hline \multirow[t]{2}{*}{ Females } & Area I & 588 & 32.0 & 107.0 & $68.91 \pm 0.66$ & 5.0 & 22.0 & $13.04 \pm 0.13$ \\
\hline & Area II & 248 & 27.0 & 112.0 & $62.92 \pm 1.06$ & 7.0 & 16.0 & $12.25 \pm 0.22$ \\
\hline
\end{tabular}

with subsequent migration of adult females to coastal waters (the area of the present study) to spawn. According to the results obtained, spawning is more intense in summer and autumn, thus favouring the greater occurrence of juveniles in the following seasons, i.e. winter and spring. Consequently, the male recruits could initiate their migration toward the offshore region before the females do. Boschi (1969) observed that as individuals of A. longinaris become 
Table 2. Percentages of juveniles and adults of Artemesia longinaris in the two collecting areas, monthly sampled between November 2003 and October 2004 in the Pinheira Beach, Palhoça, Santa Catarina.

\begin{tabular}{|c|c|c|c|c|c|c|c|c|c|c|c|c|c|}
\hline & & $\mathbf{N}$ & D & $\mathbf{J}$ & F & $\mathbf{M}$ & A & M & $\mathbf{J}$ & $\mathbf{J}$ & A & $S$ & O \\
\hline Area & Juveniles & 81 & 6.8 & 29.2 & 32.8 & 90 & 91.3 & 36.9 & 76.7 & 100 & 83 & 95 & 39.2 \\
\hline I & Adults & 19 & 93.2 & 70.8 & 67.2 & 10 & 8.7 & 63.1 & 23.3 & o & 17 & 05 & 60.8 \\
\hline Area & Juveniles & 92.5 & 9.3 & o & o & 100 & o & 100 & 43.5 & 100 & 95.9 & 98 & o \\
\hline II & Adults & 7.5 & 90.7 & 100 & 100 & 0 & 100 & 0 & 56.5 & 0 & 4.1 & 2 & 100 \\
\hline
\end{tabular}

adults and reach commercial size, they begin to migrate to deeper regions in Argentinean waters. In their study, in the State of Rio Grande do Sul, Dumont \& D'Incao (2004) proposed a similar hypothesis and Gavio \& Boschi (2004) confirmed that the main reason for this detour in the Mar del Plata region is the different breeding migrations of the males and females, because of the requirements for spawning.

Artemesia longinaris is sexually dimorphic in size, with females reaching a larger TL than males, indicating differential growth rates between sexes. The results obtained here followed the pattern obtained for this species in the States of Rio de Janeiro and São Paulo (Castilho et al., 2007a, b; Semensato \& Di Beneditto, 2008), and Argentinean waters (Boschi, 1969; Gavio \& Boschi, 2004). Boschi (1969) and Branco et al. (1999) noted that differences in body length between sexes are a general rule among penaeoid shrimps. According to Costa \& Fransozo (2004) and Castilho et al. (2008c), this sexual dimorphism probably occurs because the large body size of females is an adaptation to increased egg production.

Boschi \& Scelzo (1977) and Rodriguez et al. (2002) have found individuals that still were juveniles between the lengths (TL) of 60 to $70 \mathrm{~mm}$. If we compare the sexual maturity of females of $A$. longinaris estimated in the present study $\left(27^{\circ} \mathrm{S}\right)$ with the findings of Dumond \& D'Incao (2004) in the State of Rio Grande do Sul $\left(32^{\circ} \mathrm{S}, 17.0 \mathrm{~mm} \mathrm{CL}\right)$ and Castilho et al. (2007a) in the Mar del Plata, Argentina $\left(37^{\circ} \mathrm{S}, 22.1 \mathrm{~mm} \mathrm{CL}\right)$, we can perceive a trend toward an increase in the size at sexual maturity with increasing latitude. These authors did not mention the sexual maturity of the males. Nascimento (1981), along the coast of Rio Grande do Sul, estimated from morphological variations in the petasma, that at $10.7 \mathrm{~mm}(\mathrm{CL})$ all the males were functional adults. A similar trend appeared in relation to body size. Boschi (1997) found females as large as $30 \mathrm{~mm}$ CL in Mar del Plata, and Boschi \& Mistakidis (1966) recorded females as large as $37 \mathrm{~mm} \mathrm{CL}$ in Chubut Province $\left(43^{\circ} \mathrm{S}\right)$. In contrast, females caught on the coast of Rio Grande do Sul reached $28 \mathrm{~mm}$. Similarly to the results obtained by Castilho et al. (2007a) in the State of São Paulo, we captured adult specimens of A. longinaris that were even smaller $(<27 \mathrm{~mm} \mathrm{CL}$ ). (The authors cited did not mention the sexual maturity and body size of males.)

However, this tendency was not confirmed in comparing the results obtained for populations farther north (tropical climate, $23^{\circ} \mathrm{S}$ ). Only the sexual maturity of females was similar when our results were compared with those of Castilho et al. (2007b) on the São Paulo coast. Semensato \& Di Beneditto (2008) found that at latitude $22^{\circ} \mathrm{S}$, females reached sexual maturity at $16.4 \mathrm{~mm} \mathrm{CL}$; this is $3.0 \mathrm{~mm}$ CL larger than the size at maturity observed here, and also by Castilho et al. (2007b).
In relation to maximum body length, our estimates were the lowest in comparing two tropical regions. Perhaps, different sampling or differential migration between juveniles and adults of the populations of the two localities (south-east and south) may have contributed to this trend. Semensato \& Di Beneditto (2008) carried out their sampling in locations where the fishing fleets worked most, and therefore, few juveniles were caught. On the coast of São Paulo, Castilho et al. (2007b) sampled in a similar depth-range to this work; however, juveniles and also adults approached the coast in greater abundance only in spring or the beginning of summer. At these times, the cold water mass (South Atlantic Coastal Waters (SACW)) intrudes, and the bottom temperatures were lower than $21^{\circ} \mathrm{C}$. In the other seasons, most of the population moved to deep areas with the retreat of the SACW. In the present study area, during the winter and spring, we observed mean monthly values lower than $21^{\circ} \mathrm{C}$, which may have caused the juveniles to remain longer. Here, the adult population probably moves to shallow waters only to spawn in the first six months of the year. This may have led to similar sizes at maturity between these regions.

According to the present regulations, the fishery is closed between March to May, because this is the main recruitment period of juvenile pink shrimps (Farfantepenaeus spp.) in the entire south-east and south regions of Brazil (Costa et al., 2008). Our results indicate that the traditional fishery at Pinheira Beach acted with greatest intensity on juveniles, mainly, in winter (July to September) on both sexes. In this way, we suggest that during all winter months the region up to $30 \mathrm{~m}$ of depth should be included in the present proposed off-season.

One of the main objectives of the study of the reproductive ecology of benthic invertebrates is to assess latitudinal trends in the timing of reproduction and recruitment of juveniles (Bauer, 1992). In Pinheira Beach, the presence of juveniles throughout the year suggests that this species breeds continuously. However, there is evidence for more intense breeding activity in summer and autumn. Similar results were obtained by Castilho et al. (2007b), when the reproductive period was highest in spring and summer. In cool-temperate Argentinean waters, Christiansen \& Scelzo (1971) observed seasonal breeding and recruitment. These results, too, corroborate the classical paradigm of seasonal reproduction at higher latitudes, and continuous reproduction at lower latitudes.

In general, it can be concluded that the areas in the present study are of maximum importance for the establishment and growth of juveniles, and are a breeding ground of this species. These results can be used to develop a more appropriate fishery policy in the study region. Future studies on migration and reproduction, focusing on deeper-water sites, are especially important to clarify the hypotheses presented on the population aspects of Artemesia longinaris. 


\section{ACKNDWLEDGEMENTS}

Thanks to the Universidade do Vale do Itajaí (UNIVALI) for financial support, and to the Conselho Nacional de Desenvolvimento Científico e Tecnológico ( $\mathrm{CNPq}$ ), for a scientific productivity grant awarded to Dr Joaquim Olindo Branco. Dr Janet W. Reid revised the text.

\section{REFERENCES}

Bauer R.T. (1992) Testing generalizations about latitudinal variation in reproduction and recruitment patterns with sicyoniid and caridean shrimp species. Invertebrate Reproduction and Development 22 193-202.

Branco J.O. (2005) Biologia e pesca do camarão sete-barbas Xiphopenaeus kroyeri (Heller) (Crustacea, Penaeidae), na Armação do Itapocoroy, Penha, Santa Catarina, Brasil. Revista Brasileira de Zoologia 22, $1050-1062$

Branco J.O. and Verani J.R. (1998a) Aspectos bioecológicos do camarão-rosa Penaeus brasiliensis Latreille (Natantia, Penaeidae) da Lagoa da Conceição, Florianópolis, Santa Catarina, Brasil. Revista Brasileira de Zoologia 15, 345-351.

Branco J.O. and Verani J.R. (1998b) Estudo populacional do camarão-rosa Penaeus paulensis Pérez Farfante (Natantia, Penaeidae) na Lagoa da Conceição, Santa Catarina, Brasil. Revista Brasileira de Zoologia 15, 353-364.

Branco J.O. and Fracasso H.A.A. (2004) Ocorrência e abundância da carcinofauna acompanhante na pesca do Camarão Sete-Barbas (Xiphopenaeus kroyeri Heller) (Crustácea, Decapoda), na Armação do Itapocory, Penha, SC, Brasil. Revista Brasileira de Zoologia 21 295-301.

Branco J.O., Lunardon-Branco M.J., Souto F.X. and Guerra C.R. (1999) Estrutura populacional do camarão sete-barbas Xiphopenaeus kroyeri (Heller, 1862), na foz do rio Itajaí-Açú, Itajaí, SC, Brasil. Brazilian Archives of Biology and Technology 42, 115-126.

Boschi E.E. (1969) Estudio biológico pesquero del camarón Artemesia longinaris Bate de Mar del Plata. Boletín del Instituto Nacional de Investigación y Desarrollo Pesquero 18, 1-47.

Boschi E.E. (1997) Las pesquerías de crustáceos decápodos en el litoral de la República Argentina. Investigaciones Marinas 25, 19-40.

Boschi E.E. and Mistakidis M. (1966) Resultados preliminares de las campañas de pesca exploratoria del langostino y el camarón en Rawson, 1962-1963. Carpas FAO Technical Report 6, 1-15.

Boschi E.E. and Scelzo M.A. (1977) Desarrollo larval y cultivo del camarón comercial de Argentina Artemesia longinaris Bate (Crustacea, Decapoda, Penaeidae). FAO-Pesca 159, 287-327.

Castilho A.L., Gavio M.A., Costa R.C., Boschi E.E., Bauer R. and Fransozo A. (2007a) Latitudinal variation in population structure and reproductive pattern of the endemic South American shrimp Artemesia longinaris (Penaeoidea). Journal of Crustacean Biology 27, $548-552$.

Castilho A.L., Costa R.C., Fransozo A. and Boschi E.E. (2007b) Reproductive biology of the shrimp Artemesia longinaris Bate, 1888 (Crustacea, Decapoda, Penaeidae) in the northern Coast of São Paulo State, Brazil. Revista de Biologia Tropical 55, 39-48.

Castilho A.L., Pie M.R., Fransozo A., Pinheiro A.P. and Costa R.C. (2008a) The relationship between environmental variation and species abundance in shrimp communities (Crustacea: Decapoda: Penaeoidea) in south-eastern Brazil. Journal of the Marine Biological Association of the United Kingdom 88, 119-123.
Castilho A.L., Furlan M., Costa R.C. and Fransozo V. (2008b) Reproductive biology of the rock shrimp Sicyonia dorsalis (Decapoda, Penaeoidea) from the southeastern coast of Brazil. Invertebrate Reproduction and Development 52, 59-68.

Castilho A.L., Costa R.C., Fransozo A. and Negreiros-Fransozo M.A (2008c) Reproduction and recruitment of the South American red shrimp, Pleoticus muelleri (Crustacea, Solenoceridae), from the southeastern coast of Brazil. Marine Biology Research 4, $361-368$.

Cha K.H., Oh C-W., Hong S.Y. and Park K.Y. (2002) Reproduction and population dynamics of Penaeus chinensis (Decapoda: Penaeidae) on the western coast of Korea, Yellow Sea. Fisheries Research 56, 25-36.

Christiansen H.E. and Scelzo M.A. (1971) Ciclo de maduración sexual y observaciones sobre la morfologia del aparato genital del camarón Artemesia longinaris Bate. Carpas 16, 1-22.

Costa R.C. and Fransozo A. (2004) Reproductive biology of the shrimp Rimapenaeus constrictus (Decapoda, Penaeidae) in the Ubatuba region of Brazil. Journal of Crustacean Biology 24, 274-281.

Costa R.C., Fransozo A., Melo G.A.S. and Freire F.A.M. (2003) Chave ilustrada para identificação dos camarões Dendrobranchiata do litoral norte do estado de São Paulo, Brasil. Biota Neotropica 3, $1-12$, avaliable in http://www.biotaneotropica.org.br/v3n1.

Costa R.C., Fransozo A., Castilho A.L. and Freire F.A.M. (2005) Annual, seasonal and spatial variation of abundance of the shrimp Artemesia longinaris (Decapoda, Penaeoidea) in a south-eastern region of Brazil. Journal of the Marine Biological Association of the United Kingdom 85, 107-112.

Costa R.C., Fransozo A., Freire F.A.M. and Castilho A.L. (2007) Abundance and ecological distribution of the 'sete-barbas' shrimp Xiphopenaeus kroyeri (Heller, 1862) (Decapoda, Penaeoidea) in three bays of the Ubatuba region, southeastern Brazil. Gulf and Caribbean Research 19, 33-41.

Costa R.C., Lopes M., Castilho A.L., Fransozo A. and Simões S.M. (2008) Abundance and distribution of juveniles pink shrimps Farfantepenaeus spp. in a mangrove estuary and adjacent bay on the northern shore of São Paulo State, southeastern Brazil. Invertebrate Reproduction and Development 52, 51-58.

D'Incao F., Valentini H. and Rodrigues L.F. (2002) Avaliação da pesca de camarões nas regiões Sudeste e Sul do Brasil. 1965-1999. Atlântica $24,49-62$.

Dumont L.F.C. and D'Incao F. (2004) Estágios de desenvolvimento gonadal de fêmeas do camarão-barba-ruça (Artemesia longinarisDecapoda: Penaeidae). Iheringia, Série Zoológica 94, 389-393.

Gavio M.A. and Boschi E.E. (2004) Biology of the shrimp Artemesia longinaris Bate, 1888 (Crustacea: Decapoda: Penaeidae) from Mar del Plata coast, Argentina. Nauplius 12, 83-94.

Kevrekidis K. and Thessalou-Legaki M. (2006) Catch rates, size structure and sex ratio of Melicertus kerathurus (Decapoda: Penaeidae) from an Aegean Sea trawl fishery. Fisheries Research 80, 270-279.

Nascimento P.A.M. (1981) Variações no tamanho médio de maturação em Artemesia longinaris Bate, 1888 (Crustacea, Decapoda, Penaeidae). Naturalia 6, 33-42.

Rodriguez M., Gómez M., Verdi A. and Muniz P. (2002) Presencia de Artemesia longinaris (BATE, 1888) y peisos petrunkevitchi (BURKENROAD, 1945) (Crustacea, Decapoda) en aguas de baja salinidad en la costa de Montevideo. Boletín de la Sociedad Zoológica del Uruguay 13, 21-24.

Semensato X.E.G. and Di Beneditto A.P.M. (2008) Population dynamic and reproduction of Artemesia longinaris (Decapoda: Penaeidae) in 
Rio de Janeiro State, south-eastern Brazil. Boletim do Instituto de Pesca 34, 89-98.

Vazzoler A.E.A.M. (1996) Biologia da reprodução de peixes teleósteos: teoria e prática. Maringá: Editora Eduem.

and

Zar T.H. (1984) Biostatistical analysis. New Jersey: Prentice-Hall Inc.
Correspondence should be addressed to:

R. Caetano da Costa

LABCAM, Departamento Ciências

Biológicas-Faculdade de Ciências-UNESP

Bauru, SP, Brazil, Avenida Eng. Edmundo Carrijo Coube

s/n-Vargem Limpa, 17033-36o, Brazil

email: rccosta@fc.unesp.br 